\title{
Demography as a Determinant of Awareness, Knowledge and Attitude of Asaba Youth to Media Advocacy Campaign on Sickle Cell Disorder
}

\author{
Kolade Ajilore ${ }^{1}$, Kevin Onyenankeya ${ }^{2}$, Emmanuel Morka ${ }^{3}$, Mofoluke Akoja ${ }^{1}$, \\ Babafemi Akintayo $^{1} \&$ Olusegun Ojomo ${ }^{1}$ \\ ${ }^{1}$ Veronica Adeleke School of Social Sciences, Babcock University, Ilisan-Remo, Ogun State, Nigeria \\ ${ }^{2}$ Department of Communication, University of Fort Hare, Alice, South Africa \\ ${ }^{3}$ Department of Mass Communication, Delta State Polytechnic, Ogwashi, Uku, Delta State, Nigeria \\ Correspondence: Kevin Onyenankeya, Department of Communication, University of Fort Hare, Alice, South \\ Africa.
}

Received: April 17, 2018 Accepted: September 18, 2018 Online Published: October 13, 2018

doi:10.5539/gjhs.v10n11p19 URL: https://doi.org/10.5539/gjhs.v10n11p19

\begin{abstract}
In a localized attempt to address the inevitable status of Nigeria as the biggest host of patients of sickle cell anaemia, the Delta state government sponsored a media centered initiative to attract public attention to sickle cell disease as well as to the victims of the disorder. This study examined the influence of the media advocacy campaign on youth's awareness, knowledge and attitude to the disease using the questionnaire survey method involving 300 participants randomly selected from the capital city, Asaba. The results showed that demographic variables such as age, gender, income and religious affiliations had varying influence on awareness, knowledge and attitude of respondents. Although respondents exhibited modest awareness and knowledge of the disorder, it emerged that they arrived at this level of knowledge through information acquired from sources other than the state sponsored media campaign on sickle cell. The study concluded that the media advocacy campaign on sickle cell disorder was yet to resonate with the target population.
\end{abstract}

Keywords: demography, asaba youth, sickle cell disorder

\section{Introduction}

Sickle cell is a genetic disorder characterized by gene mutation which changes the molecular haemoglobin by stiffening the red blood cells and giving it sickle shape when oxygen is released into the blood vessels. These sickle-shaped cells get caught in the narrow blood vessels, blocking the flow of oxygenated blood which results in painful crisis in the joints and bones of those affected. The sickle cell gene is transmitted genetically, from parent-to-child. When a carrier of the sickle cell gene mates with another carrier or sickle cell disease patient, it results in an offspring of either carrier or sickle cell disease. Symptoms of this disease include excessive fatigue or irritability from anaemia, fussiness in babies, bedwetting from associated kidney problems, jaundice, swelling and pain in hands and feet, frequent infections and pain in the chest, back, arms or legs (Ighoraye \& Ighoraye, n.d.). Due to the inadequacies of the healthcare system in Nigeria, only five percent of children with the disease live past the age of 10.The average life span of a sickle cell carrier is 20 years (Akinsete, 2016; Alege, 2015).

The issue of sickle cell disorder (SCD) remains a major concern globally particularly in Sub-Saharan Africa, where it is mostly prevalent. According to the World Health Organisation (2006:1), the disease is common in Africa because the sickle cell trait confers some resistance to falciparum malaria during a critical period of early childhood, favouring survival of the host and subsequent transmission of the abnormal haemoglobin gene. There is increasing evidence that malaria not only influences outcome but also changes the manifestation of sickle-cell anaemia in Africa. Due to the fact that those affected hardly make it beyond age five, it has become a major contributor to infant mortality ratio in this part of the world where poverty is highly prevalent and healthcare is not a national priority. In Nigeria, out of a population of about 170 million, 150,000 are born with the disease (SS) annually, while about 40 million are healthy carriers of the AS gene (Akenzua, 2017; Akinsete, 2016; Ugbe, 2016). One of the demands of this disease on victims is frequent visits to the hospital and the visible effect of this for most affected families, is the financial burden it places on them. Olatunya et al. (2015) in their study of 111 households of victims of sickle cell disease in Ekiti State of Nigeria, found that most of these families were from the low social 
class and as such often offset hospital bills with loans. Apart from the financial burden, the disease interferes with every aspect of the patient's life including "education, employment and psychological development" (Alege, 2015, para.4). Equally, Adewoyin, Alagbe, Adedokun and Idubor (2015:35) assert that "sickle cell disease runs a chronic course, that is characterised by repeated ill-health, progressive organ damage and shortened life-span". The physiological cum financial strain associated with the disorder has been exacerbated by misconceptions linked to the manifestations of the condition. Stakeholders have attributed the myth and erroneous beliefs around sickle cell disease to the low level of awareness on the inheritable nature of the disease and poor knowledge of genotype compatibility (Alege, 2015; Akinsete, 2016). A lot of misconceptions about the disease exist even among the enlightened citizens. The study by Ugwu (2016) on the awareness, knowledge and attitude of Nigerian undergraduates, found that there are various mistaken beliefs associated with the disease among the youths. For instance, some people believe the disease is caused by witchcraft or evil spirits, while some believe sickle cell is a contagious disease that is unpreventable. Ugwu's finding underscores the fact that a knowledge gap exist in certain population which only a comprehensive and sustained health communication can help address. Health communication is one of the most effective communication strategies targeted at achieving change in attitude globally. US Department of Health and Human Services (2005 in Schiavo, 2007:34) define health communication as "the art and techniques of informing, influencing, motivating individual, institutional, and public audiences about important health issues". Carpenter and Sherbino (2011) argue that opinion leaders play influential roles in health practice and communication. Although sometimes poorly coordinated and targeted, government, non-governmental organisations as well as individuals at the national, state and communal levels, have continued to make efforts to curb the high occurrence of the disease. Also, there has been several outreach programmes, seminars, club activities, and social events to bring succour to sufferers of sickle cell (Akenzua, 2017; Akinsete, 2016, Alege, 2015). Until 2008 when the World Health Organisation recognised sickle cell disease as an important public health condition, efforts at combating the disease nationally, were characterised by poor coordination (Olatunya \& Adekile, 2017). The intervention by WHO led to a spate of actions on sickle cell disease including the formation of the Nigerian sickle cell disease network popularly referred to as Sickle Cell Support Society of Nigeria in 2010, and the launch of the first national guidelines for the control and management of sickle cell disease in Nigeria in 2014.

Delta State Government is one of the stakeholders at the forefront of the efforts at combating the disease. Over the years the state has introduced a couple of strategies to fight the sickle cell scourge. This involves the setting up of several sickle cell clinics at different locations across the state, collaborating with the media through various advocacy campaigns targeted at increasing awareness among the people. The ' 05 Initiative' launched in 2017 is also intended to leverage the media to intensify the awareness campaign on preventive measures at combating the epidemic. The ' 05 Initiative' uses the mass media such as radio, television, newspapers to disseminate information that underscore the importance of youths knowing their genotype and getting professional genetic counselling, (Ministry of Health, Asaba, n.d.). The campaign is premised on the theoretical assumptions of the agenda setting theory which holds that the mass media determines the issues or topics for public discussion and the degree of attention and interest accorded to them. It is assumed that if the media deliberately sets the issue of sickle cell disorder as a subject of public attention, there is the likelihood that the general audience will learn from the information provided and ultimately, resolve to take the right action which is to control the spread of this disease.

\subsection{Purpose}

For several decades, the media have been at the forefront of different advocacy campaigns targeted at achieving specific objectives including increasing knowledge, changing attitude and perception of people to issues affecting quality of life. The media in Nigeria is one of the agents often utilised for this purpose. In spite of the sustained media coverage on the scourge of sickle cell, the disorder remains a major health challenge in Nigeria. It is therefore important to interrogate the effectiveness of media campaigns in bridging the gap in knowledge and dispelling the myths and cultural beliefs around sickle cell disease. In other words, it is important to find out why the several media campaigns have failed to gain traction with the populace especially towards changing their attitude to sickle cell disease. Using the youth in Asaba, Delta state, Nigeria as a point of departure, this study investigated the influence of the " 05 Initiative" media campaign in creating awareness, knowledge and attitude change towards sickle cell disease. Additionally, the study examined the role demographic factors such as age, gender, education and religious affiliation play on the knowledge and attitude of youth to sickle cell disease. It was hypothesised that: (1) Age will significantly influence awareness of, knowledge and attitude towards sickle cell disease (2) Gender will significantly influence awareness of, knowledge and attitude towards sickle cell disease (3) Education will significantly influence awareness of, knowledge of and attitude towards sickle cell disease (4) Religious affiliation will significantly influence awareness of, knowledge and attitude towards sickle cell disease 
and, (5) Awareness will significantly influence the association between knowledge and attitude towards sickle cell disease.

\section{Area Description}

The study was conducted in Asaba, the capital of Delta State. This state falls within the Niger-Delta region of Nigeria and has a population of 94, 082 (National Population Commission, 2017). Asaba is a metropolitan city with a relatively well developed infrastructure compared to other settlements in the state. The research respondents were limited to bachelors and spinsters because they were the target of the two year old media advocacy campaign. The cut-off age for participation was set at eighteen because of the sensitivity of the issue.

\section{Method}

\subsection{Procedure}

Being an effective measure for generating quantitative data for ease of generalisation, the questionnaire survey method was used involving 300 participants. The questionnaire had two sections - items in section A captured respondents demographic details while section B adopted the Likert rating scale in measuring levels of awareness, knowledge and attitude of respondents on the subject of sickle cell disorder. Participants who were either bachelors or spinsters from 18 years and above, were randomly selected using a multi-stage sampling technique. The sample was drawn from four streets randomly selected from three wards (ward 2, 7 and 11). The twenty-item questionnaire was content validated by ensuring that constructs in the study align with the questionnaire items while reliability yielded a Cronback Alpha score of 0.867 . Out of the 300 copies of questionnaire distributed, 282 were found valid for analysis.

As the end of the fieldwork exercise involving the field coordinator and three research assistants, 299 copies were turned in from the 300 copies of the questionnaire administered. The data cleaning exercise revealed 288 usable copies. The hypotheses or research questions presume that there is a significant relationship between the variables being considered, therefore the pre-set level of significance for this study is 0.05 . If the P-value which indicates the significance or the probability value exceeds the pre-set level of significance $(\mathrm{P}>0.05)$, the hypothesis stated in alternative form will be rejected, however, if the $\mathrm{P}$-value is less than or equal to $0.05(\mathrm{P} \leq 0.05)$, the hypothesis will be accepted. The data were presented using measures of central tendency, simple linear regression and stepwise regression.

\section{Results}

As indicated in Table 1, majority of the participants were between the ages of 18 and 27. Females constituted more than half of the population (53\%), while overwhelming majority of participants were Christians (82\%). Majority of the participants (68\%) possessed O'Level qualifications while $32 \%$ had higher level of academic qualifications (Table 1).

Table 1. Demographic Characteristics of Respondents

\begin{tabular}{llll}
\hline Variable & & Frequency $(\mathbf{n})$ & Percentage (\%) \\
\hline Age & $18-22$ & 153 & 54.3 \\
& $23-27$ & 111 & 39.4 \\
& $28-32$ & 18 & 6.4 \\
& Total & $\mathbf{2 8 2}$ & $\mathbf{1 0 0 . 0}$ \\
\hline Gender & Male & 134 & 47.5 \\
& Female & 148 & 52.5 \\
& Total & $\mathbf{2 8 2}$ & $\mathbf{1 0 0 . 0}$ \\
\hline \multirow{3}{*}{ Religion } & Christianity & 230 & 81.6 \\
& Islam & 52 & 18.4 \\
& Total & $\mathbf{2 8 2}$ & $\mathbf{1 0 0 . 0}$ \\
\hline \multirow{3}{*}{ Education } & WASSC/O'Level & 191 & 67.7 \\
& HND/BSc & 91 & 32.3 \\
& Total & $\mathbf{2 8 2}$ & $\mathbf{1 0 0 . 0}$ \\
\hline
\end{tabular}




\subsection{Awareness of Sickle Cell Disorder by Respondents}

Majority of the respondents agreed that they were aware of sickle cell disease (Table 2). However, many of the respondents were ignorant of the government sponsored media campaign on sickle cell disease (Mean=2.20, $\mathrm{SD}=1.74)$. This suggests that the Delta state media campaign has not gained traction with majority of the youth. This could be due to poor coordination of the campaign. This finding implies that participants 'existing knowledge on sickle cell disease may have been acquired from sources outside the media.

Participants demonstrated high level of knowledge with regards to the symptoms of and causes of sickle cell disease (Average Weighted Mean=4.53, $\mathrm{SD}=0.73$ ). Overwhelming majority of the respondents agreed sickle cell patients are always sickly (Mean $=4.61, \mathrm{SD}=0.49$ ) and the disorder is hereditary (Mean= 4.45, $\mathrm{SD}=0.97$ ). This finding is in sharp contrast to previous research in the Eastern part of the country which found that there were many misconceptions about the causes of the disease (Ugwu, 2016). It may be that the awareness and education programme on the sickle cell disease is high in Asaba compared to the state were the previous study took place.

Table 2. Awareness and knowledge of Sickle Cell Disorder by respondents

\begin{tabular}{|c|c|c|}
\hline \multicolumn{3}{|l|}{ Awareness } \\
\hline I have heard of sickle cell disease & 4.40 & 1.25 \\
\hline Delta State government recently carried out a campaign on SCD & 2.20 & 1.74 \\
\hline Average Weighted Mean & 3.30 & 1.50 \\
\hline \multicolumn{3}{|l|}{ Knowledge } \\
\hline SCD patients are always sickly & 4.61 & 0.49 \\
\hline SCD is a hereditary disorder from parents & 4.45 & 0.97 \\
\hline Average Weighted Mean & 4.53 & 0.73 \\
\hline \multicolumn{3}{|c|}{$\begin{array}{l}\text { KEY: } S A=\text { Strongly Agree, } A=\text { Agree, } D=\text { Disagree, } S D=\text { Strongly Disagree, NI=No Idea } * * * \text { Decision Rule if mean is } \leq 1.49 \\
=\text { No Idea; } 1.5 \text { to } 2.49=\text { Strongly Disagree; } 2.5 \text { to } 3.49=\text { Disagree; } 3.5 \text { to } 4.49=\text { Agree; } 4.5 \text { to } 5=\text { Strongly Agree. }\end{array}$} \\
\hline \multicolumn{3}{|l|}{ 4.2 Attitude of Respondents Towards Sickle Cell Disorder } \\
\hline \multicolumn{3}{|c|}{$\begin{array}{l}\text { Participants generally were empathetic towards sufferers of sickle cell anaemia (Average Weighted Mean }=3.70 \text {, } \\
\mathrm{SD}=0.99 \text { ). Majority of the participants agreed sickle cell sufferers should be shown love and care }(\text { Mean }=4.52) \text {. } \\
\text { Preponderance of the participants disagreed with the statement that parents of sickle cell children should be } \\
\text { avoided (Mean }=2.88, \mathrm{SD}=0.99 \text { ). This positive disposition to sickle cell victims and their parents may be as a result } \\
\text { of improved knowledge on the nature of sickle cell. One of the problems mitigating against the effective } \\
\text { management and control of this disease over the years has been the problem of stigmatization following the belief } \\
\text { that the disease is contagious (Ugwu, 2016). }\end{array}$} \\
\hline
\end{tabular}

Table 3. Attitude of respondents towards Sickle Cell Disorder

\begin{tabular}{lll}
\hline Items & Mean & SD \\
\hline SCD patients should be loved and cared for & 4.52 & 1.00 \\
SCD patients should be avoided & 2.88 & 0.99 \\
Average Weighted Mean & $\mathbf{3 . 7 0}$ & $\mathbf{0 . 9 9}$ \\
\hline
\end{tabular}

KEY: $\mathrm{SA}=$ Strongly Agree, $\mathrm{A}=$ Agree, $\mathrm{D}=$ Disagree, $\mathrm{SD}=$ Strongly Disagree, NI=No Idea***Decision Rule if mean is $\leq 1.49$ =No Idea; 1.5 to $2.49=$ Strongly Disagree; 2.5 to $3.49=$ Disagree; 3.5 to $4.49=$ Agree; 4.5 to $5=$ Strongly Agree.

\subsection{Medium of Exposure to Sickle Cell Disease Messages}

As indicated in Table 4, most participants stated that they learnt about sickle cell disorder in school from their teachers (Mean=3.86, $\mathrm{SD}=1.19$ ) and counsellors (Mean=3.53, $\mathrm{SD}=1.09)$. This suggests that media were not the overarching channels through which participants acquired information about sickle cell disease (Average 
Weighted Mean= 3.33, $\mathrm{SD}=1.21$ ). This may explain why participants are unaware of the government sponsored media campaigns on sickle cell.

Table 4. Media/Medium of Exposure to SCD by respondents

\begin{tabular}{lll}
\hline Items & Mean & SD \\
\hline I heard of SCD at School from my teachers & 3.86 & 1.19 \\
I heard of SCD from other counselors & 3.53 & 1.09 \\
I heard of SCD from my parents & 3.42 & 0.97 \\
I heard of SCD on radio & 3.29 & 1.62 \\
I heard of SCD from my friends & 3.28 & 1.19 \\
I came across sickle cell in the social media & 3.24 & 1.22 \\
I heard of sickle cell on T V & 3.23 & 1.36 \\
I heard of SCD at a health workshop by an health agency/NGO & 3.21 & 1.00 \\
I heard of SCD at a church/Islamic organized marriage programme & 3.20 & 1.22 \\
I read of SCD in newspaper /magazine & 2.99 & 1.22 \\
\hline Average Weighted Mean & $\mathbf{3 . 3 3}$ & $\mathbf{1 . 2 1}$
\end{tabular}

KEY: $\mathrm{SA}=$ Strongly Agree, $\mathrm{A}=$ Agree, $\mathrm{D}=$ Disagree, $\mathrm{SD}=$ Strongly Disagree, $\mathrm{NI}=$ No Idea $^{* * *}$ Decision Rule if mean is $\leq 1.49$ =No Idea; 1.5 to $2.49=$ Strongly Disagree; 2.5 to $3.49=$ Disagree; 3.5 to $4.49=$ Agree; 4.5 to $5=$ Strongly Agree.

\subsection{Influence of Demographics on Awareness, Knowledge and Attitude Towards Sickle Cell Disease}

It was found that age inversely influenced level of awareness, in the sense that older participants (age range 18 to 32) were less aware of sickle cell disease than their young counterpart. In table 5a, age significantly explains variability of awareness of sickle cell disease $(p<0.05)$. Similarly, age had a significant negative influence on participants' knowledge $(\mathrm{p}<0.05)$. As with awareness; chronological age affected the pattern and strength of knowledge in a reverse order where the younger respondents appeared more knowledgeable about sickle cell disease than the older respondents. Furthermore, age exerted significant influence on participants attitude towards sickle cell disease $(\mathrm{p}<0.05)$. The younger respondents exhibited more sympathetic attitude towards sickle cell disease than the older participants. This result is surprising given that the burden of care for sickle cell victims usually falls on older people who are either parents or relatives.

Table 5a. Regression analysis predicting the influence of age on awareness, knowledge and attitude towards sickle cell disease (SCD)

\begin{tabular}{|c|c|c|c|c|c|c|c|c|c|}
\hline \multirow{2}{*}{ Variable } & \multicolumn{3}{|c|}{ Model_Hypothesis 1} & \multicolumn{3}{|c|}{ Model_Hypothesis 2} & \multicolumn{3}{|c|}{ Model_Hypothesis 3} \\
\hline & Coeff & t-Stat. & Prob. & Coeff & t-Stat. & Prob. & Coeff & t-Stat. & Prob. \\
\hline $\mathrm{C}$ & 6.592 & 33.502 & 0.000 & 7.473 & 42.035 & 0.000 & 5.490 & 34.046 & 0.000 \\
\hline Age & -0.338 & -6.014 & 0.000 & -0.250 & -4.321 & 0.000 & -0.138 & -2.329 & 0.021 \\
\hline $\mathrm{R}^{2}$ & \multicolumn{3}{|l|}{0.114} & \multicolumn{3}{|l|}{0.063} & \multicolumn{3}{|l|}{0.019} \\
\hline Adj. $\mathrm{R}^{2}$ & \multicolumn{3}{|l|}{0.111} & \multicolumn{3}{|l|}{0.059} & \multicolumn{3}{|l|}{0.016} \\
\hline F-Statistic & \multicolumn{3}{|l|}{36.163} & \multicolumn{3}{|l|}{18.697} & \multicolumn{3}{|l|}{5.424} \\
\hline Prob.(F-Stat) & \multicolumn{3}{|l|}{$0.000^{*}$} & \multicolumn{3}{|l|}{$0.000^{*}$} & \multicolumn{3}{|l|}{$0.021^{*}$} \\
\hline Dependent Variable & \multicolumn{3}{|c|}{ Awareness SCD } & \multicolumn{3}{|c|}{ Knowledge SCD } & \multicolumn{3}{|c|}{ Attitude SCD } \\
\hline
\end{tabular}

The result in table $5 \mathrm{~b}$ shows that females were more likely to have improved awareness (positive relationship) of sickle cell disease than males (inverse relationship) $(\mathrm{p}<0.05)$. This suggests that gender plays a significant role in the level of awareness of sickle cell disorder. Males on the other hand, were likely to be more knowledgeable 
(positive relationship) about sickle cell disorder than their female counterparts (inverse relationship). Table $5 \mathrm{~b}$ shows that the male gender explains improved variability in knowledge of sickle cell disease $\left(p<0.05, R^{2}=0.071\right)$. But females were also more favourably disposed to sickle cell than males $(\mathrm{p}<0.05)$.

Table $5 \mathrm{~b}$. Regression analysis predicting the influence of gender on awareness, knowledge and attitude towards sickle cell disease (SCD)

\begin{tabular}{|c|c|c|c|c|c|c|c|c|c|}
\hline \multirow{2}{*}{ Variable } & \multicolumn{3}{|c|}{ Model_Hypothesis 4} & \multicolumn{3}{|c|}{ Model_Hypothesis 5} & \multicolumn{3}{|c|}{ Model_Hypothesis 6} \\
\hline & Coeff & t-Stat. & Prob. & Coeff & t-Stat. & Prob. & Coeff & t-Stat. & Prob. \\
\hline $\mathrm{C}$ (Male) & 5.757 & 54.501 & 0.000 & 6.470 & 6.470 & 0.000 & 5.311 & 64.103 & 0.000 \\
\hline $\mathrm{C}$ (Female) & 5.205 & 46.891 & 0.000 & 7.082 & 73.673 & 0.000 & 4.955 & 56.912 & 0.000 \\
\hline Male & -0.210 & -3.599 & 0.000 & 0.266 & 0.266 & 0.000 & -0.174 & -2.959 & 0.003 \\
\hline Female & 0.210 & 3.599 & 0.000 & -0.266 & -4.616 & 0.000 & 0.174 & 2.959 & 0.003 \\
\hline $\mathrm{R}^{2}$ (Male) & 0.044 & & & 0.071 & & & 0.030 & & \\
\hline $\mathrm{R}^{2}$ (Female) & 0.044 & & & 0.071 & & & 0.030 & & \\
\hline Adj. $\mathrm{R}^{2}$ (Male) & 0.041 & & & 0.067 & & & 0.027 & & \\
\hline Adj. $R^{2}$ (Female) & 0.041 & & & 0.067 & & & 0.027 & & \\
\hline F-Statistic (Male) & 12.955 & & & 21.307 & & & 8.754 & & \\
\hline F-Statistic (Female) & 12.955 & & & 21.307 & & & 8.754 & & \\
\hline Prob.(F-Stat) (Male) & $0.000^{*}$ & & & $0.000^{*}$ & & & $0.003^{*}$ & & \\
\hline Prob.(F-Stat) (Female) & $0.000^{*}$ & & & $0.000 *$ & & & $0.003 *$ & & \\
\hline Dependent Variable & Awaren & s SCD & & Knowle & $\mathrm{SCD}$ & & Attitu & $\mathrm{CD}$ & \\
\hline
\end{tabular}

As indicated in table $5 \mathrm{c}$ level of education had no significant influence on awareness of sickle cell disease $(\mathrm{p}>0.05)$, but education positively influenced level of knowledge $(p<0.05)$ and attitude $(p<0.05)$ towards sickle cell disease. In other words, increase in education was likely to result in improved knowledge about the symptoms and causes of sickle cell disorder and favourable attitude to victims.

Table $5 \mathrm{c}$. Regression analysis predicting the influence of education on awareness, knowledge and attitude towards sickle cell disease (SCD)

\begin{tabular}{|c|c|c|c|c|c|c|c|c|c|}
\hline \multirow{2}{*}{ Variable } & \multicolumn{3}{|c|}{ Model_Hypothesis 7} & \multicolumn{3}{|c|}{ Model_Hypothesis 8} & \multicolumn{3}{|c|}{ Model_Hypothesis 9} \\
\hline & Coeff & t-Stat. & Prob. & Coeff & t-Stat. & Prob. & Coeff & t-Stat. & Prob. \\
\hline $\mathrm{C}$ & 5.420 & 23.080 & 0.000 & 6.186 & 30.468 & 0.000 & 4.571 & 25.497 & 0.000 \\
\hline Level Education & 0.020 & 0.338 & 0.736 & 0.177 & 3.002 & 0.003 & 0.198 & 3.376 & 0.001 \\
\hline $\mathrm{R}^{2}$ & \multicolumn{3}{|l|}{0.000} & \multicolumn{3}{|l|}{0.031} & \multicolumn{3}{|l|}{0.039} \\
\hline Adj. $\mathrm{R}^{2}$ & \multicolumn{3}{|l|}{-0.003} & \multicolumn{3}{|l|}{0.028} & \multicolumn{3}{|l|}{$0 . .036$} \\
\hline F-Statistic & \multicolumn{3}{|l|}{0.114} & \multicolumn{3}{|l|}{9.015} & \multicolumn{3}{|l|}{11.473} \\
\hline Prob.(F-Stat) & \multicolumn{3}{|l|}{0.736} & \multicolumn{3}{|l|}{0.003} & \multicolumn{3}{|l|}{0.001} \\
\hline Dependent Variable & \multicolumn{3}{|c|}{ Awareness SCD } & \multicolumn{3}{|c|}{ Knowledge SCD } & \multicolumn{3}{|c|}{ Attitude SCD } \\
\hline
\end{tabular}

Surprisingly, the results in table $5 \mathrm{~d}$ show that religion had little effect on participants' awareness $(\mathrm{F}(1,280)=$ $0.022, \mathrm{p}>0.05)$, knowledge $(\mathrm{F}(1,280)=1.458, \mathrm{p}>0.05)$ and attitude $(\mathrm{F}(1,280)=0.043, \mathrm{p}>0.05)$ towards sickle cell disease. 
Table 5d. Regression analysis predicting the influence of religion on awareness, knowledge and attitude towards sickle cell disease (SCD)

\begin{tabular}{|c|c|c|c|c|c|c|c|c|c|}
\hline \multirow{2}{*}{ Variable } & \multicolumn{3}{|c|}{ Model_Hypothesis 10} & \multicolumn{3}{|c|}{ Model_Hypothesis 11} & \multicolumn{3}{|c|}{ Model_Hypothesis 12} \\
\hline & Coeff & t-Stat. & Prob. & Coeff & t-Stat. & Prob. & Coeff & t-Stat. & Prob. \\
\hline $\mathrm{C}$ & 5.459 & 21.704 & 0.000 & 7.013 & 31.832 & 0.000 & 5.180 & 26.449 & 0.000 \\
\hline Religion & 0.009 & 0.149 & 0.882 & -0.072 & -1.207 & 0.228 & -0.012 & -0.206 & 0.837 \\
\hline $\mathrm{R}^{2}$ & \multicolumn{3}{|l|}{0.000} & \multicolumn{3}{|l|}{0.005} & \multicolumn{3}{|l|}{0.000} \\
\hline Adj. $R^{2}$ & \multicolumn{3}{|l|}{-0.003} & \multicolumn{3}{|l|}{0.002} & \multicolumn{3}{|l|}{-0.003} \\
\hline F-Statistic & \multicolumn{3}{|l|}{0.022} & \multicolumn{3}{|l|}{1.458} & \multicolumn{3}{|l|}{0.043} \\
\hline Prob.(F-Stat) & \multicolumn{3}{|l|}{0.882} & \multicolumn{3}{|l|}{0.228} & \multicolumn{3}{|l|}{0.837} \\
\hline Dependent Variable & \multicolumn{3}{|c|}{ Awareness SCD } & \multicolumn{3}{|c|}{ Knowledge SCD } & \multicolumn{3}{|c|}{ Attitude SCD } \\
\hline
\end{tabular}

4.5 Determining the Influence of Awareness on the Relationship Between Knowledge and Attitude Towards Sickle Cell Disease

As can be seen in table 6 , awareness significantly influenced the association between knowledge and attitude towards genotype compatibility $(\mathrm{F}(2,279)=11.083, \mathrm{p}<0.05)$. This implies that when participants are aware of sickle cell disease, they stand the chance of acquiring knowledge and developing attitudinal disposition towards sickle cell disease. In other words, awareness of sickle cell disease helps to bring about a significant interaction between knowledge and attitude towards sickle cell disease. In the first regression model, knowledge of sickle cell disease explain 3.8 percent variation in attitude towards sickle cell disease $\left(p<0.05, R^{2}=0.038\right)$. However, when awareness is introduced in the second model, there was a change of 3.6 percent in the degree of explanation of attitude towards sickle cell disease $\left(\mathrm{p}<0.05, \mathrm{R}^{2}=0.074\right)$. This suggests that awareness of sickle cell disease will more likely improve knowledge and attitude towards sickle cell disease, hence, awareness of genotype sickle cell disease is foundational and important for acquisition of knowledge and positive attitude towards sickle cell disease.

Table 6. Stepwise Regression Testing the Influence that Awareness has on the Association between Knowledge and Attitude towards sickle cell disease

\begin{tabular}{|c|c|c|c|c|c|c|c|}
\hline \multirow{2}{*}{ Variable } & \multicolumn{3}{|c|}{ Model 1_Hypothesis 13} & \multirow{2}{*}{ Variable } & \multicolumn{3}{|c|}{ Model 2_Hypothesis 13} \\
\hline & Coeff & t-Stat. & Prob. & & Coeff & t-Stat. & Prob. \\
\hline $\mathrm{C}$ & 3.981 & 11.166 & 0.000 & $\mathrm{C}$ & 4.452 & 11.764 & 0.000 \\
\hline \multirow[t]{2}{*}{ Knowledge } & 0.194 & 3.304 & 0.001 & Knowledge & 0.258 & 4.243 & 0.000 \\
\hline & & & & Awareness & -0.201 & -3.297 & 0.000 \\
\hline $\mathrm{R}^{2}$ & 0.038 & & & & 0.074 & & \\
\hline Adj. $\mathrm{R}^{2}$ & 0.034 & & & & 0.067 & & \\
\hline F-Statistic & 10.914 & & & & 11.083 & & \\
\hline Prob.(F-Stat) & $0.001 *$ & & & & $0.000 *$ & & \\
\hline Dependent Variable & \multicolumn{4}{|c|}{ Attitude SCD } & \multicolumn{3}{|c|}{ Attitude SCD } \\
\hline
\end{tabular}

\section{Discussion}

The study showed that age inversely influenced level of awareness as the older the participants get, the less aware they are of sickle cell disease, the less their knowledge about sickle cell disease and the less they exhibited a sympathetic attitude towards sickle cell disease. Females were also found to have more improved awareness (positive relationship) of sickle cell disease than males (inverse relationship), males were found to be more 
knowledgeable (positive relationship) about sickle cell disorder while females were more favourably disposed to sickle cell. In addition, it was established that an increase in education may not improve awareness but it may positively improve knowledge about the symptoms and causes of sickle cell disorder as well as yield a favourable attitude to victims. Religion on the other hand, had little influence on participants' awareness, knowledge and attitude towards sickle cell disease.

Generally, the findings indicate an improvement in awareness and knowledge about the causes and symptoms of sickle cell among participants. This is consistent with the findings of Olatunya and Adekile (2017) which state that awareness and knowledge about sickle cell has been in upswing since 2008. The defining contribution of this study lies in the revelation that school teachers and counsellors and not the media, were the primary sources of information about sickle cell. This underscores the important role of opinion leaders in information dissemination. As Valente and Pumuang (2007) note, opinion leaders can act as gatekeepers for interventions, achieving change in social norms and accelerating behavior change. Carpenter and Sherbino (2010) holds that adoption of new knowledge, skills or attitudes will include social influence of individuals such as the opinion leaders within the group.

Although respondents exhibited modest awareness and knowledge of the sickle cell disorder, this knowledge appear not to have emanated from the state sponsored media campaign on sickle cell. Meaning that the campaign was yet to resonate with the target population. This suggest a failure of either the campaign strategy or the execution of the idea. The poor coordination of the campaign and failure to streamline the target audience may be a plausible explanation why it failed to gain traction with the youth. It was gratifying to find that participants exhibited positive attitude and empathy with the sufferers of sickle cell and their parents. Previous studies have found that people avoided victims and their family based on the erroneous belief that the disease was contagious (Ugwu, 2016). This development is likely to deflate the stigmatisation of sickle cell sufferers and their families. The findings no doubt will enrich the knowledge of and guide how health communication practitioners design their campaign. More importantly, the findings implies that demographic variables of the audience should be taken into consideration when designing health communication campaigns. If possible, different messages should be designed and customized for audiences based on their gender, age, and education.

\section{Conclusion}

The findings of this study demonstrate that demographic variables such as age, gender, education and religious leaning influence the awareness, knowledge and attitude of youths in Asaba towards sickle cell anaemia. As evinced from participants, the government sponsored media advocacy on sickle cell disorder was yet to resonate with the population as many participants are not even aware that such campaign exists. The findings suggest that teachers and counsellors could be more effective channel of waging the awareness and education campaign on sickle cell. This highlights the need for a complete overhaul of the campaign in a way that will bring about optimal outcome.

\section{Competing Interests Statement}

The authors declare that there are no competing or potential conflicts of interest.

\section{References}

Adewoyin, A. S., Alagbe, A. E., Adedokun, B. O., \& Idubor, N. T. (2015). Knowledge, attitude and control practices of sickle cell disease among youth corps members in Benin City, Nigeria. Annals of Ibadan postgraduate medicine, 13(2), 100-107.

Akenzua, G. (2017). Nigeria has the highest burden of sickle cell anaemia - experts. The Street Journal. Retrieved from http://thestreetjournal.org/2017/05/nigeria-has-world-highest-burden-of-sickle-cell-anemia-experts/

Akinsete, A. (2016). 150,000 children are born in Nigeria with sickle cell disease in Nigeria. ThisDay

Alege, L. (2015). Sickle Cell Disease: Nigeria has largest cases in the world. Retrieved from: https://www.vanguardngr.com/2015/06/sickle-cell-disease-nigeria-has-largest-cases-in-the-world-research/

Carpenter, C. R., \& Sherbino, J. (2010). How does an "opinion leader" influence my practice? CJEM, 12(5), 431. https://doi.org/10.1017/S1481803500012586

Ighoraye, C., \& Ighoraye, O. (n.d.). Sickle cell at a glance. Brochure on save a life know your genotype today. Dame Edith Okowa 05 Initiative.

Ministry of Health Asaba. (n.d.). Sickle cell anaemia: a sickle cell warrior by the Sickle cell clinic, Delta State. Dame Edith Okowa 05 Initiative. 
Olatunya, O. S., \& Adekile, A. D. (2017). What every physician should know about the national guidelines for control and management of sickle cell disease and the parent handbook for sickle cell in Nigeria. Nigerian Journal of Clinical Practice, 20(1), 123-125. https://doi.org/10.4103/1119-3077.195541

Olatunya, O. S., Ogundare, E. O., Fadare, J. O., Oluwayemi, I. O., Agaja, O. T., Adeyefa, B. S., \& Aderiye, O. (2015). The financial burden of sickle cell disease on households in Ekiti, Southwest Nigeria. ClinicoEconomics and outcomes research: CEOR, 7, 545. https://doi.org/10.2147/CEOR.S86599

Schiavo, R. (2013). Health communication: From theory to practice. John Wiley \& Sons.

Ugwu, N. I. (2016) Sickle cell disease awareness, knowledge and attitude among undergraduates of a Nigerian Tertiary Institution. Asian Journal of Medical Sciences, 7(5), 82-92. https://doi.org/10.3126/ajms.v7i5.15044

Valente, T. W., \& Pumpuang, P. (2007). Identifying opinion leaders to promote behavior change. Health Education \& Behavior, 34(6), 881-896. https://doi.org/10.1177/1090198106297855

World Health Organisation [WHO]. (2006) Sickle cell anaemia report by secretariat. Fifty-ninth world health $\begin{array}{lllllll}\text { assembly a59/9 } & \text { Provisional agenda } & \text { item } & 11.4 & \text { Retrieved }\end{array}$ http://apps.who.int/gb/archive/pdf_files/WHA59/A59_9-en.pdf

\section{Copyrights}

Copyright for this article is retained by the author(s), with first publication rights granted to the journal.

This is an open-access article distributed under the terms and conditions of the Creative Commons Attribution license (http://creativecommons.org/licenses/by/4.0/). 